\title{
The effect of body fatness on energetic efficiency and fasting heat production in adult sheep
}

\author{
BY MARY A. MCNIVEN* \\ Department of Animal Nutrition, Agricultural University of Norway, \\ 1432 Aas- $N L H$, Norway
}

(Received 14 February 1983 - Accepted 25 October 1983)

\begin{abstract}
1. The effect of body fatness on the fasting heat production and energetic efficiency of adult sheep was studied.
2. Energy balance and heat production were determined in adult wether sheep at three fatness levels given a diet of grass hay and maize at four feeding levels, including fasting, in open-circuit respiration chambers. The sheep weighed approximately $60 \mathrm{~kg}$ at the start and were fed over a period of 4-7 months to obtain one of three levels of bodyfatness: fat $90 \mathrm{~kg}$, medium $70 \mathrm{~kg}$ and thin $55 \mathrm{~kg}$.

3. Neither the digestibility nor the metabolizability of the diet was affected by body fatness or feeding level.

4. Average fasting heat production was $6.47,7.00$ and $8.20 \mathrm{MJ} / \mathrm{d}$ for the thin, medium and fat sheep respectively, but when expressed as a multiple of metabolic body size $\left(\mathrm{kg} \mathrm{W}^{0.75}\right)$ remained constant at $0.31 \mathrm{MJ} / \mathrm{kg} \mathrm{W0.75}$.

5. At each level of feeding the fat sheep produced most heat, but when heat production was expressed as a multiple of fasting heat production or metabolic body size, the differences due to level of fatness disappeared. Heat increment was not affected by fatness and there was no suggestion that energy utilization was improved by loss of condition.

6. It is concluded that white adipose tissue is highly active and contributes significantly to the maintenance energy requirements of adult sheep. Metabolic body size is a good unit of reference for comparison of energy metabolism in adult animals of the same species but varying in body size.
\end{abstract}

In adult animals a change in body-weight is, for the most part, a change in the amount of fat tissue in the body. The contribution of this change to the energetic efficiency of the animal is important for both experimental and practical reasons. Wide variation in the amounts of fat deposited is a common physiological characteristic of both domestic and wild ruminant species.

The high-producing dairy cow must rely heavily on body fat reserves as an energy source in early lactation when the genetic drive to produce milk exceeds the ability to ingest food. Moe et al. (1971) showed that the over-all efficiency of fat deposition in late lactation and subsequent mobilization of this tissue in early lactation is almost as great as the efficiency of dietary energy utilization. However, the energy costs of maintaining this fat tissue during late lactation and the dry period have not been considered in this comparison.

In tropical countries with alternating dry and rainy seasons, ruminants are forced to deposit large amounts of body fat during the growing season and, to a great extent, survive on these body reserves during the dry season. Similarly, in Scandinavia, reindeer used for meat production deposit great amounts of fat (up to $50 \%$ body-weight) during the summer on which to survive during the scarcity of winter.

In accepting the occurrence of these phenomena, nutritionists must consider this reserve tissue as making a significant contribution to the total metabolism of the body and the extent to which it may influence the computation of total energy requirements.

Metabolic processes such as lipid turnover are energy dependent and so inevitably produce heat. As yet, however, little is known about the quantitative contribution of these individual processes to the over-all basal expenditure of an animal (MacRae \& Lobley, 1982). There is evidence that basal release of glycerol from adipose tissue, i.e. basal lipolysis, is a function of the size of the fat cell (Smith, 1970). As fat cells enlarge, the basal rate of

* Present address: 70 Cambridge Avenue, Apt. 1731, Toronto, Ontario M4K 2L5, Canada. 
lipolysis increases but the effect of this increase on the total metabolic rate of the animal is not clear.

Lean body-weight has been suggested as a more correct basis for energy requirements compared with metabolic body size (kg body-weight ${ }^{075}$ ) (e.g. Chesters, 1975; Pullar \& Webster, 1977; Toutain et al. 1977) in animals with large amounts of body fat since this tissue is considered to be less active metabolically than lean tissue. However, conflicting reports exist (e.g. Graham, 1967; Deb et al. 1976; Blaxter et al. 1982; McCracken \& McNiven, 1983), suggesting that fat tissue does contribute significantly to the energy requirement of the animal.

An understanding of the effects of body-weight change in ruminants on their energy requirements and efficiency is both of practical relevance and importance in relation to the design and interpretation of many experiments. Consequently, the present experiment was designed to study the effect of body fatness on heat production and energetic efficiency at three levels of nutrition and fasting in adult wethers.

\section{EXPERIMENTAL}

\section{Animals and diets}

Preliminary balance and respiration trials were conducted to determine the metabolizable energy (ME) content of the food used in the main experiment and to measure fasting heat production (FHP). Twenty trials were made on ten wethers ranging in weight from 45 to $85 \mathrm{~kg}$, both at a maintenance level of feeding and at fasting. The animals, originally weighing about $60 \mathrm{~kg}$, were given food at different planes of feeding to obtain a wide range of body-weights.

In the main experiment, nine adult crossbred wethers were used. At the start of the experiment the sheep all weighed about $60 \mathrm{~kg}$. The animals were randomly allotted to different planes of feeding to obtain three levels of body fatness expressed by body-weights: fat $90 \mathrm{~kg}$, medium $70 \mathrm{~kg}$ and thin $55 \mathrm{~kg}$. The sheep were weighed twice weekly prior to the morning feed when crushed maize and high-quality grass hay were given on a $50: 50(\mathrm{w} / \mathrm{w})$ basis for all feeding levels. After a period of 4-7 months, required to reach expected body-weights, balance and respiration measurements were made at four planes of nutrition for each of the three levels of body fatness: high $1500 \mathrm{~g}$ food/d, intermediate $900 \mathrm{~g} / \mathrm{d}$, low $600 \mathrm{~g} / \mathrm{d}$ and fasting. The intermediate level always preceded the fasting measurements. The foods were from the same batch.

An experimental period consisted of a $7 \mathrm{~d}$ adjustment period followed by a collection period of $7 \mathrm{~d}$ in which the excreta were collected quantitatively and frozen at $-18^{\circ}$ until analysed. For the fasting trials, only urine was collected.

The animals were accustomed to the metabolism cages and respiration chambers. Rations were given in equal meals at $12 \mathrm{~h}$ intervals and fresh water was available at all times. The animals received sufficient digestible protein, minerals and vitamins without supplementation according to published standards ((US) National Academy of Sciences/National Research Council, 1975). In the main experiment, one sheep in the thin group died of causes not related to the experiment.

\section{Chemical analysis}

Samples of food, refusals and fresh excreta were analysed for nitrogen by the Kjeldahl method; energy content was determined by use of an adiabatic bomb calorimeter, urine first being freeze-dried and faeces oven-dried.

The proximate composition of the food and faeces was determined by the standard AOAC methods (Association of Official Agricultural Chemists, 1970). 
Table 1. Chemical composition and digestibility of the diet

\begin{tabular}{lccc}
\hline Constituent & $\begin{array}{c}\text { As fed } \\
(\%)\end{array}$ & $\begin{array}{c}\text { DM } \\
(\%)\end{array}$ & $\begin{array}{c}\text { Digestibility } \\
(\%)\end{array}$ \\
\hline Dry matter (DM) & $90 \cdot 5$ & - & $77 \cdot 0$ \\
Organic matter & $86 \cdot 2$ & $95 \cdot 2$ & $80 \cdot 9$ \\
Crude protein & $12 \cdot 1$ & $13 \cdot 4$ & $68 \cdot 4$ \\
Crude fibre & $15 \cdot 4$ & $17 \cdot 0$ & $76 \cdot 5$ \\
Energy (MJ/kg) & 17.07 & $18 \cdot 86$ & $77 \cdot 8$ \\
\hline
\end{tabular}

* Nitrogen $\times 6.25$.

\section{Respiration trials}

The two open-circuit respiration chambers used for the determination of heat and methane production were described by Sundstol et al. (1974). For the trials when the sheep were given food, the sheep were placed in the chambers for a $2 \mathrm{~d}$ adjustment period and then heat production measured at $18^{\circ}$ for three $24 \mathrm{~h}$ periods and averaged. For the fasting trials, the sheep were placed in the chambers for a $2 \mathrm{~d}$ adjustment period without food and then heat production measured for two $24 \mathrm{~h}$ periods (days 3 and 4 of fast) and averaged. During the fasting trials urine was collected quantitatively and analysed for $\mathrm{N}$ and energy.

\section{Statistical analysis}

Statistical analysis was performed using the Statistical Analysis System (SAS Institute Inc., 1982) and Student's $t$ test.

\section{RESULTS}

\section{Diet}

The average chemical composition and digestibility of the diet for all trials are shown in Table 1.

ME content of the feed was not affected by the extent of fatness in the sheep as shown in Fig. 1. There was no difference in digestibility or metabolizability between the preliminary trial and the main experiment.

The average energy balance results for the three levels of fatness in the main experiment are shown in Table 2 . The individual values for the fat animals tended to be more variable than those of the medium or thin animals.

\section{FHP}

In the preliminary experiment, twenty respiration trials were conducted on adult wethers ranging in weight from 45 to $85 \mathrm{~kg}$ to determine FHP on the $3 \mathrm{rd}$ and 4 th days of fasting. The relationship between MJ FHP and $\mathrm{kg}$ body-weight (W) was found to be expressed by the power equation FHP $=a \mathrm{~W}^{b}$. There was no significant difference $(t$ test, $P<0.05$ ) between the exponent $b(0 \cdot 76)$ and the accepted interspecies mean value of $0 \cdot 75$, the power of weight which is commonly used to define metabolic size, and the mean (with SD) FHP $/ \mathrm{kg}$ metabolic body size was found to be $0.35(0.04) \mathrm{MJ}$.

In the main experiment, the average FHP was $6.47,7.00$ and $8.20 \mathrm{MJ} / \mathrm{d}$ for the thin $(54 \mathrm{~kg})$, medium $(63 \mathrm{~kg})$ and fat $(82 \mathrm{~kg})$ sheep respectively. The average (with SD) FHP $/ \mathrm{kg}$ metabolic body size was $0.31(0.03) \mathrm{MJ}$ for all fatness levels and there was no significant difference ( $t$ test) between the values for the three levels of fatness. 


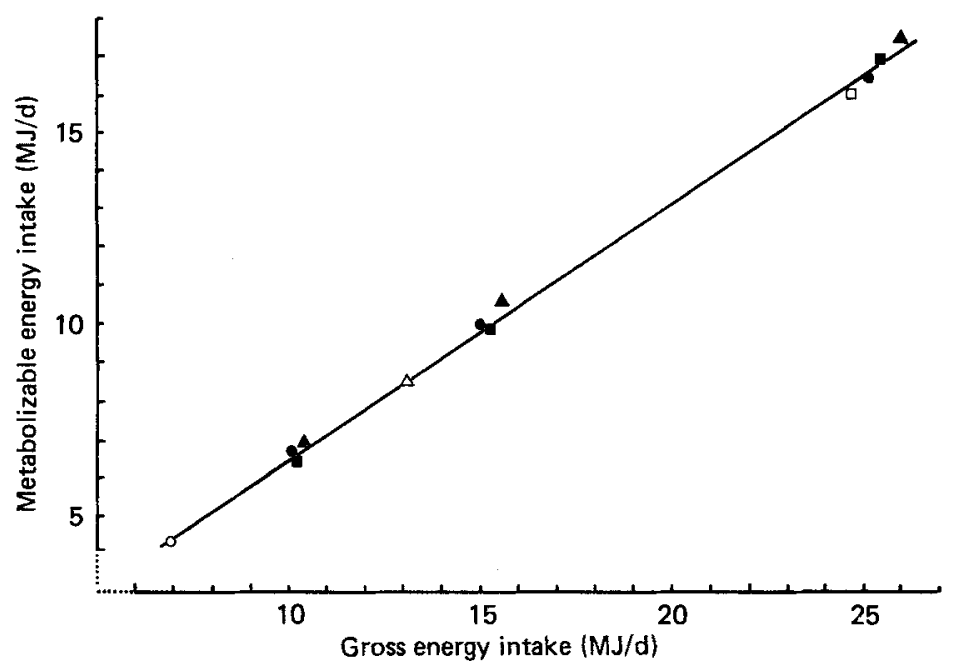

Fig. 1. Relationship between metabolizable energy intake $\left(\mathrm{ME}_{\mathrm{I}} ; \mathrm{MJ} / \mathrm{d}\right)$ and gross energy intake $\left(\mathrm{GE}_{\mathrm{I}}\right.$; $\mathrm{MJ} / \mathrm{d})$ for the preliminary trial $(n 20)(O$, thin; $\triangle$, medium; $\square$, fat sheep) and for the main experiment ( $n$ 24) (, thin; $\boldsymbol{\Lambda}$, medium; $\boldsymbol{\square}$, fat sheep). Common linear regression equation for both trials was: $\mathrm{ME}_{\mathrm{T}}=0.67 \mathrm{GE}_{\mathrm{I}}-0.23, \quad r^{2} 0.9901(P<0.001)$.

Each point is the mean of three or four observations.

Table 2. Average energy balance results for the fat, medium and thin sheep on the same diet at three levels of feeding

\begin{tabular}{|c|c|c|c|c|c|c|c|c|c|}
\hline \multirow[b]{2}{*}{ Size } & \multirow[b]{2}{*}{$n$} & \multirow[b]{2}{*}{$\begin{array}{l}\text { Feeding } \\
\text { level* }\end{array}$} & \multirow{2}{*}{$\begin{array}{l}\text { Mean } \\
\text { weight } \\
(\mathrm{kg})\end{array}$} & \multirow{2}{*}{$\begin{array}{c}\text { Gross } \\
\text { energy } \\
(\mathrm{GE}) \\
(\mathrm{MJ} / \mathrm{d})\end{array}$} & \multirow{2}{*}{$\begin{array}{c}\text { Digestible } \\
\text { energy } \\
(\mathrm{DE}) \\
(\mathrm{MJ} / \mathrm{d})\end{array}$} & \multicolumn{2}{|c|}{ Energy in } & \multirow{2}{*}{$\begin{array}{c}\text { Metabolizable } \\
\text { energy } \\
\text { (\% GE) }\end{array}$} & \multirow{2}{*}{$\begin{array}{c}\text { Heat } \\
\text { production } \\
(\mathrm{MJ} / \mathrm{d})\end{array}$} \\
\hline & & & & & & $\begin{array}{l}\text { Urine } \\
(\% \mathrm{DE})\end{array}$ & $\begin{array}{l}\text { Methane } \\
(\% \text { DE) }\end{array}$ & & \\
\hline Fat & $\begin{array}{l}3 \\
3 \\
3\end{array}$ & $\begin{array}{l}\text { H } \\
\text { I } \\
\text { L }\end{array}$ & $\begin{array}{l}88 \cdot 3 \\
84 \cdot 5 \\
83 \cdot 3\end{array}$ & $\begin{array}{l}25 \cdot 46 \\
15 \cdot 28 \\
10 \cdot 18\end{array}$ & $\begin{array}{r}19.77 \\
11.80 \\
7.87\end{array}$ & $\begin{array}{l}2.79 \\
3.77 \\
5.79\end{array}$ & $\begin{array}{l}12 \cdot 0 \\
12 \cdot 0 \\
13 \cdot 3\end{array}$ & $\begin{array}{l}66 \cdot 2 \\
65 \cdot 1 \\
62 \cdot 6\end{array}$ & $\begin{array}{l}14 \cdot 1 \\
11 \cdot 6 \\
10 \cdot 7\end{array}$ \\
\hline Medium & $\begin{array}{l}3 \\
3 \\
3\end{array}$ & $\begin{array}{l}\text { H } \\
\text { I } \\
\text { L }\end{array}$ & $\begin{array}{l}68 \cdot 8 \\
67 \cdot 2 \\
62 \cdot 8\end{array}$ & $\begin{array}{l}26 \cdot 03 \\
15 \cdot 62 \\
10 \cdot 41\end{array}$ & $\begin{array}{r}20 \cdot 16 \\
12 \cdot 46 \\
8 \cdot 27\end{array}$ & $\begin{array}{l}3.22 \\
3.91 \\
5.08\end{array}$ & $\begin{array}{l}10 \cdot 3 \\
11 \cdot 3 \\
12 \cdot 0\end{array}$ & $\begin{array}{l}67 \cdot 0 \\
67 \cdot 5 \\
66 \cdot 0\end{array}$ & $\begin{array}{r}13 \cdot 7 \\
10 \cdot 1 \\
9 \cdot 8\end{array}$ \\
\hline Thin & $\begin{array}{l}2 \\
2 \\
2\end{array}$ & $\begin{array}{l}\text { H } \\
\text { I } \\
\text { L }\end{array}$ & $\begin{array}{l}59 \cdot 0 \\
56 \cdot 5 \\
50 \cdot 6\end{array}$ & $\begin{array}{l}25 \cdot 18 \\
15 \cdot 11 \\
10 \cdot 07\end{array}$ & $\begin{array}{r}18 \cdot 96 \\
11 \cdot 72 \\
7 \cdot 86\end{array}$ & $\begin{array}{l}3 \cdot 98 \\
2 \cdot 27 \\
4 \cdot 53\end{array}$ & $\begin{array}{r}9.6 \\
12 \cdot 5 \\
12.6\end{array}$ & $\begin{array}{l}65 \cdot 1 \\
66 \cdot 1 \\
66 \cdot 4\end{array}$ & $\begin{array}{r}12 \cdot 1 \\
9 \cdot 4 \\
7 \cdot 4\end{array}$ \\
\hline
\end{tabular}

* H, high; 1 , intermediate; L, low.

\section{Energetic efficiency}

The relationship between heat production (HP) and $M E$ intake $\left(\mathrm{ME}_{\mathrm{I}}\right)$ for the three fatness levels is shown in Fig. 2. At any given level of feeding, the fat sheep had a greater HP than the thin sheep, the medium sheep being intermediate.

The linear regression equations for the relationship between $\mathrm{HP}(\mathrm{MJ} / \mathrm{d})$ and $\mathrm{ME}_{\mathrm{I}}(\mathrm{MJ} / \mathrm{d})$ are as follows:

Fat $\mathrm{HP}=0.35 \mathrm{ME}_{\mathrm{I}}+8.21, \quad r^{2} 0.8773(P<0.001)$

Medium HP $=0.37 \mathrm{ME}_{\mathrm{I}}+6.93, \quad r^{2} 0.8998(P<0.001)$

Thin $\mathrm{HP}=0.35 \mathrm{ME}_{\mathrm{I}}+5.95, \quad r^{2} 0.9201(P<0.001)$ 


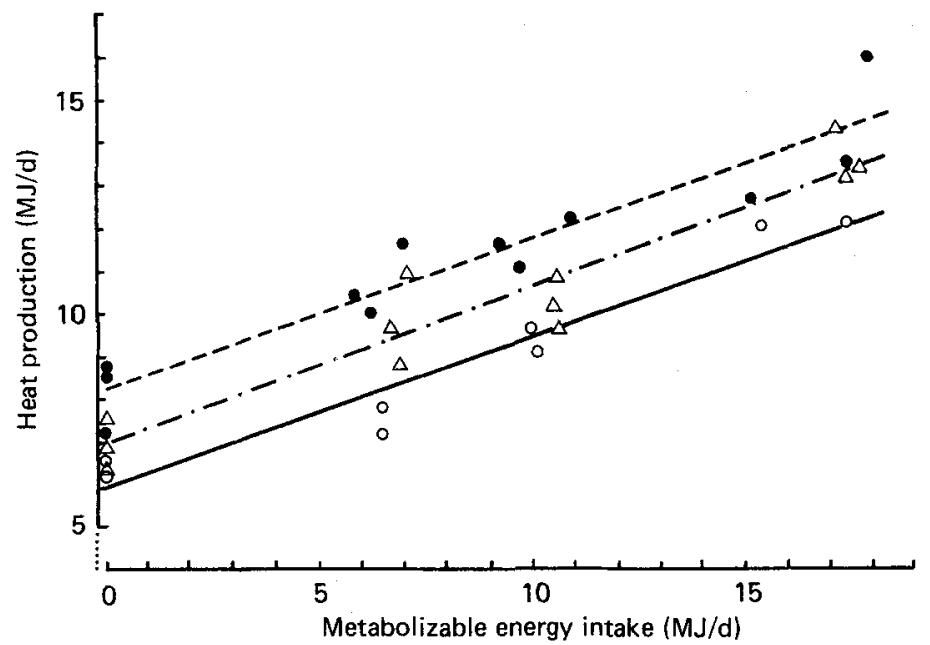

Fig. 2. Heat production (MJ/d) plotted against metabolizable energy intake (MJ/d) for (O) fat, $(\triangle)$ medium and $(O)$ thin sheep.

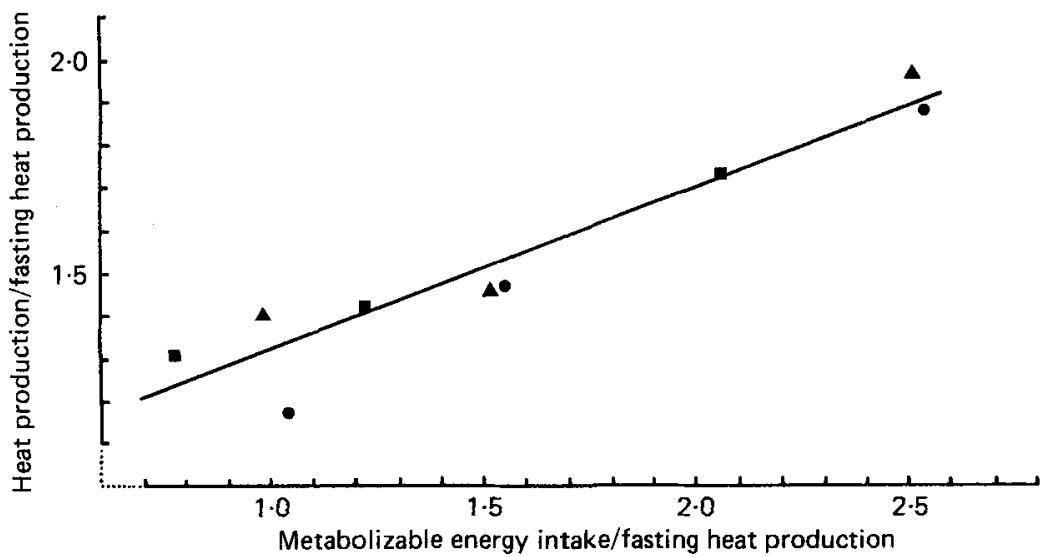

Fig. 3. Heat production (MJ/d) plotted against metabolizable energy intake $(\mathrm{MJ} / \mathrm{d})$, both expressed as multiples of the fasting heat production $(\mathrm{MJ} / \mathrm{d})$ for $(O)$ fat, $(\triangle)$ medium and $(O)$ thin sheep.

The regression coefficients were not significantly different ( $t$ test). Thus, the rate of change of $\mathrm{HP}$ with $\mathrm{ME}_{\mathrm{I}}$, i.e. heat increment, was not different for the three levels of body fatness. The difference in intercepts was tested and found to be significant $(P<0.001)$. However, when HP was expressed/ $\mathrm{kg}$ metabolic body size, the differences disappeared and the relationship for the three fatness levels fitted one common equation:

$$
\mathrm{HP} / \mathrm{kg} \mathrm{W}^{0.75}=0.01 \mathrm{ME}_{\mathrm{I}}+0.31, \quad r^{2} 0.8266(P<0.001) \text {. }
$$

When HP and ME $\mathrm{E}_{\mathrm{I}}$ were expressed as multiples of FHP (Graham, 1969) the results from the three fatness groups were found to fit a single linear regression equation shown in Fig. 3.

$$
\mathrm{HP} / \mathrm{FHP}=0.38 \mathrm{ME}_{\mathrm{I}} / \mathrm{FHP}+0.94, \quad r^{2} 0.8376(P<0.001) .
$$

This demonstrates that regardless of body fatness the sheep had the same net efficiency 


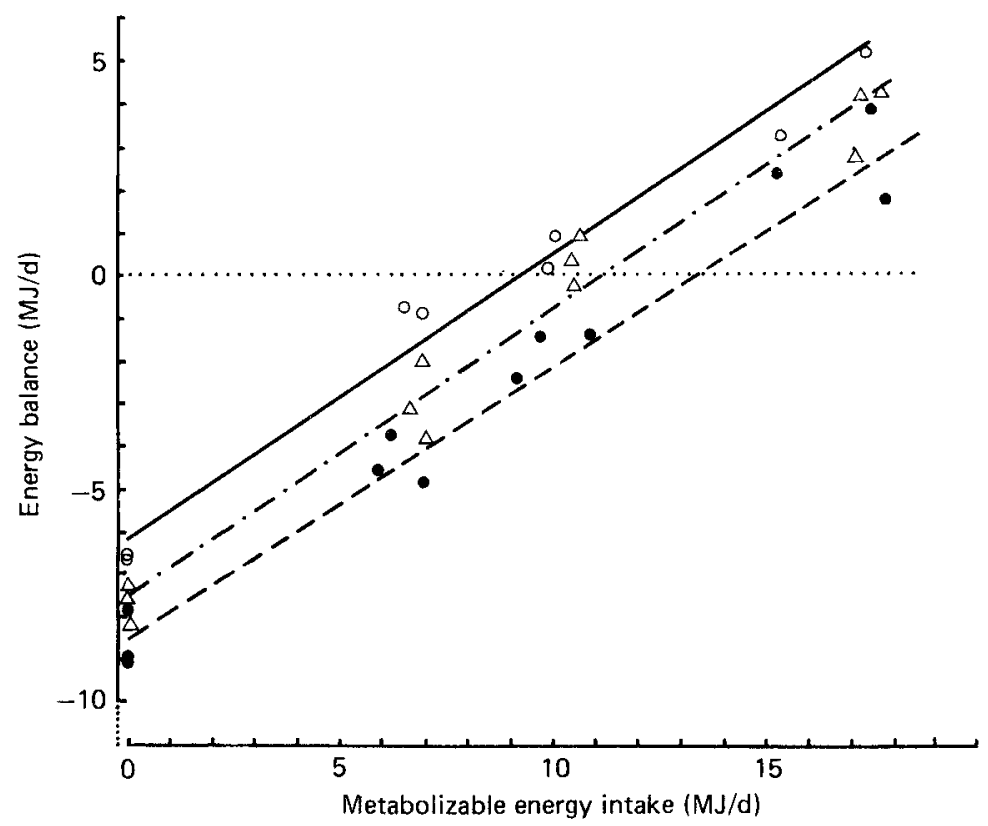

Fig. 4. Energy balance $(\mathrm{MJ} / \mathrm{d})$ plotted against metabolizable energy intake $(\mathrm{MJ} / \mathrm{d})$ for $(\bullet)$ fat, $(\triangle)$ medium and $(O)$ thin sheep.

(utilization of an increment of ME) at any given level of energy storage relative to maintenance requirements.

Energy balance was calculated by subtracting the HP from the $M E_{I}$ for each sheep and each feeding level. The relationship between energy balance (EB; $M J / d)$ and $M E_{1}$ is shown in Fig. 4. At any given level of intake the thin sheep had the greatest energy balance and the fat sheep the lowest.

The linear regression equations for this relationship are as follows:

$$
\begin{gathered}
\text { Fat EB }=0.67 \mathrm{ME}_{\mathrm{I}}-8.53, \quad r^{2} 0.9650(P<0.001) \\
\text { Medium EB }=0.67 \mathrm{ME}_{1}-7.52, \quad r^{2} 0.9641(P<0.001) \\
\text { Thin EB }=0.67 \mathrm{ME}_{1}-6.21, \quad r^{2} 0.9709(P<0.001)
\end{gathered}
$$

Parallelism was found in these regression equations and the intercepts for each equation were significantly different $(P<0.001)$.

From this relationship it was possible to determine the ME requirement at zero EB, i.e. maintenance energy requirement, and this was found to be $12 \cdot 71,11 \cdot 17$, and $9 \cdot 27 \mathrm{MJ} / \mathrm{d}$ for the fat, medium and thin sheep respectively.

When the energy balance was expressed $/ \mathrm{kg}$ metabolic body size the relationship for the three fatness levels fitted well one common linear regression equation:

$$
\mathrm{EB} / \mathrm{kg} \mathrm{W}^{0.75}=0.03 \mathrm{ME}_{\mathrm{I}}-0.32, \quad r^{2} 0.9274(P<0.001)
$$

\section{DISCUSSION}

\section{Diet}

In the present experiment, the digestible energy and ME contents of the diet were not significantly affected by either body fatness or feeding level. Blaxter (1974) reviewed calorimetric experiments with sheep and showed that the change in apparent metaboliz- 
ability of a diet with change in feeding level depends upon the fibre content of the diet. In general, the metabolizability declines with increasing feeding level only when the fibre content of the organic matter of the diet exceeds $160 \mathrm{~g} / \mathrm{kg}$. Below $160 \mathrm{~g} / \mathrm{kg}$ the general finding is that the metabolizability of the diet increases with level of feeding. In the present experiment the crude fibre content of the organic matter of the feed was about $170 \mathrm{~g} / \mathrm{kg}$ and, consistent with this, no major effect of feeding level was expected or found.

No problem in feed consumption was encountered for any of the groups of sheep on the high level of intake. This is contrary to the study of Graham (1969), who showed with fat sheep that voluntary intake declined steadily as body-weight increased to a high level (from 50 to $75 \mathrm{~kg}$ ). The length of time on high level of intake may have been the reason for these differences since, in Graham's study, the sheep were given the high level for up to 14 months, which is 4-7 months longer than the sheep in the present experiment. It is possible that consumption problems could have arisen with extended feeding periods.

\section{FHP}

In the main part of the present experiment, the average FHP $/ \mathrm{kg}$ metabolic body size was $0.31 \mathrm{MJ}$ for wethers ranging in weight from 50 to $90 \mathrm{~kg}$. This agrees well with the results of Blaxter et al. (1982), who found a mean value of $0.32 \mathrm{MJ} / \mathrm{kg} \mathrm{W}^{0.75}$. There was no significant difference between the groups of sheep when FHP was expressed as a multiple of metabolic body size and therefore it would appear from the results of this study that metabolic body size can be used to predict FHP in sheep varying greatly in body fat content.

The results of the two experiments confirm that, over a wide range of body-weight and condition, the FHP of adult sheep may be regarded as directly proportional to metabolic body size. This statement is in agreement with the results of McCracken \& Gray (1976), Deb et al. (1976) and McCracken \& McNiven (1983) with rats and Blaxter et al. (1982) with sheep.

In the present experiment, body composition determinations were not made but it is unlikely that lean body mass would increase in adult sheep so greatly as to cause the FHP to increase from 6.47 to $8.20 \mathrm{MJ} / \mathrm{d}$ as recorded for the thin and fat sheep respectively. Consequently, it must be concluded that metabolism of fat tissue must have contributed largely to this increased heat production.

Webster (1981) reviewed several articles from the literature and suggested that, in sheep and rats, maintenance energy requirements were better expressed as a function of lean mass than of weight and that fat metabolism (excluding brown adipose tissue) contributed little to heat production.

Similar results were found by Sundstol et al. (1979) with lean and fat pigs, and they suggested that the lean pigs had a greater mass of active lean tissue and therefore higher heat production.

One explanation for this discrepancy could be the method of animal selection. In the sheep experiment cited by Webster (1981) (Toutain et al. 1977) and in the pig experiment of Sundstol et al. (1979), the animals were selected for fatness or leanness from the population and this may, in fact, have been selection of animals having inherently higher or lower total metabolic rates, emphasizing the large individual differences between animals but perhaps complicating the position regarding individual tissue contribution to metabolism. In the pig experiment (Sundstol et al. 1979) the fat and lean animals were given equal amounts of food, and if the thin pigs had higher individual maintenance requirements there would be less energy remaining to deposit as fat.

In Graham's extensive experiments $(1964,1967,1969)$, which were not included by Webster (1981), and in the present experiments the sheep were of similar weight at the start of the experiments in order to minimize individual differences in metabolic rate. 


\section{Energetic efficiency}

The present experiment demonstrated that the relationship between energy storage and feed intake was essentially the same for fat and thin sheep. Because FHP varies with body-weight within, as well as between, animals and is important in the relationship between intake and storage, comparisons between animals of different weight are complicated. Graham (1969) suggested that expression of both intake and storage as multiples of FHP is one way of simplifying such comparisons without altering the calculation of efficiency. It relates directly to the efficiency complex and makes the animal's net energy requirement for maintenance the unit. The importance of standardizing conditions for measuring FHP and the costs and time involved do not make this method of calculation practical under many conditions.

In the present experiment the rate of change of heat production with $\mathrm{ME}_{\mathrm{I}}$ (heat increment) was similar for all three fatness levels. Graham (1964) showed that this rate of change became greater as the sheep lost condition. It is clear that energy utilization is not improved by loss of condition as suggested by Quimby (1948). However, a greater level of feed consumption may be obtained for thin sheep resulting in higher productivity and therefore higher gross efficiency.

The number of observations in each group of sheep did not allow differentiation between linear and allometric regression equations for energy balance and $M E_{I}$ in order to determine if net efficiencies were different above or below maintenance. However, it is clear that the differences between the three fatness levels were statistically significant $(P<0.001)$ at any given level of feed intake and that the efficiencies with which $\mathrm{ME}_{\mathrm{I}}$ from 0 to $18 \mathrm{MJ} / \mathrm{d}$ were utilized, were similar for the three groups.

Whole-body metabolism is the integration of a wide variety of metabolic rates in different tissues. The present results support the view that white adipose tissue is highly active and contributes significantly to the maintenance energy requirement. Metabolic body size (kg $\mathrm{W}^{\mathbf{0}}{ }^{75}$ ) appears to be a good unit of reference for comparison of energy metabolism in adult animals of the same species but varying in body size (McCracken \& McNiven, 1983).

This study was supported by the Norwegian Agricultural Research Council.

REFEREN CES

Association of Official Analytical Chemists (1970). Official Methods of Analysis, 11th ed. Washington, DC: Association of Official Analytical Chemists.

Blaxter, K. L. (1974). Nutrition Conference for Feed Manufacturers, no. 7, pp. 3-26 [H, Swan and D. Lewis, editors]. London: Butterworths.

Blaxter, K. L., Fowler, V. R. \& Gill, J. C. (1982). Journal of Agricultural Science, Cambridge 98, $405-420$.

Chesters, J. K. (1975). Proceedings of the Nutrition Society 34, 104 A.

Deb, S., Martin, R. J. \& Hershberger, T. V. (1976). Journal of Nutrition 106, 191-197.

Graham, N. McC. (1964). Australian Journal of Agricultural Research 15, 113-126.

Graham, N. McC. (1967). Australian Journal of Agricultural Research 18, 127-136.

Graham, N. McC. (1969). Australian Journal of Agricultural Research 20, 375-385.

McCracken, K. J. \& Gray, R. (1976). EAAP Publ. no. 19, pp. 141-144.

McCracken, K. J. \& McNiven, M. A. (1983). British Journal of Nutrition 49, 193-202.

MacRae, J. C. \& Lobley, G. E. (1982). Livestock Production Science 9, 447-456.

Moe, P. W., Tyrrell, H. F. \& Flatt, W. P. (1971). Journal of Dairy Science 54, 548-553.

National Academy of Sciences/National Research Council (1975). Nutrient Requirements of Domestic Animals

No. 5, Nutrient Requirements of Sheep, 5th ed. Washington DC: National Academy of Sciences.

Pullar, J. D. \& Webster, A. J. F. (1977). British Journal of Nutrition 37, 335-363.

Quimby, F. H. (1948). Journal of Nutrition 36, 177-186.

SAS Institute Inc. (1982). SAS User's Guide: Statistics 1982 Edition, Cary, N.C.: SAS Institute Inc.

Smith, U. (1970). FEBS Letters 11, 8-10.

Sundstol, F., Ekern, A. \& Haugen, A. E. (1974). EAAP Publ. No. 14, pp. 249-251.

Sundstol, F., Standal, N. \& Vangen, O. (1979). Acta Agriculturae Scandinavica 29, 337-345.

Toutain, P.-L., Toutain, C., Webster, A. J. F. \& McDonald, J. D. (1977). British Journal of Nutrition 38, $445-454$.

Webster, A. J. F. (1981). Proceedings of the Nutrition Society 40, 121-128. 